\title{
Uncertainty in the impacts of projected climate change on the hydrology of a subarctic environment: Liard River Basin
}

\author{
R. Thorne \\ School of Geography and Earth Sciences, McMaster University, Hamilton, Ontario, Canada
}

Received: 30 April 2010 - Published in Hydrol. Earth Syst. Sci. Discuss.: 21 May 2010

Revised: 12 April 2011 - Accepted: 3 May 2011 - Published: 17 May 2011

\begin{abstract}
Like many high latitude areas, the mountainous region of subarctic Canada has experienced recent warming and is an area of large inter-annual temperature variations, most notably during the winter. Quantifying how climate tendencies affect streamflow, especially in the spring melt season, is critical not only to regional water resource management, but to understanding the influence of freshwater on the Arctic sea-ice cover and global climate system. The impact of projected atmospheric warming on the discharge of the Liard River is unclear. Here, uncertainty in climate projections associated with GCM structure $\left(2{ }^{\circ} \mathrm{C}\right.$ prescribed warming) and magnitude of increases in global mean air temperature $\left(1\right.$ to $\left.6^{\circ} \mathrm{C}\right)$ on the river discharge are assessed using a well-tested, semi-distributed hydrological model. Analyses have shown that the hydrological impacts are highly dependant on the GCM scenario. Uncertainties between the GCM scenarios are driven by the inconsistencies in projected spatial variability and magnitude of precipitation, rather than warming temperatures. Despite these uncertainties, the entire scenario simulations project that the subarctic nival regime will be preserved in the future, but the magnitude of change in river discharge is highly uncertain. Generally, spring freshet will arrive earlier, autumn to spring discharge will increase whereas summer flow will decrease, leading to an overall increase in annual discharge.
\end{abstract}

\section{Introduction}

A quantitative understanding of the runoff response of subarctic rivers to climate change and variability is important for planning and development, environmental conservation, social well-being and the livelihood of communities on valleys

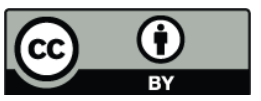

Correspondence to: $\mathrm{R}$. Thorne (thornerf@mcmaster.ca) and flood plains. The Mackenzie River is the largest river in North America that brings freshwater from the subarctic and Arctic environments in Canada to the Arctic Ocean. The mountainous Liard River Basin, an area that has experienced warming in recent decades (Zhang et al., 2000) is a major tributary of the Mackenzie River. Freshwater input to the Arctic Ocean from the Mackenzie River forms a surface layer on the denser saline seawater that allows the formation of sea ice. The extent and duration of the sea ice cover, in turn, affects oceanic evaporation and hence, moisture and heat fluxes into the Arctic atmosphere. An increase in freshwater discharge will reduce sea ice volume and thereby potentially reduce thermohaline circulation (Rennermalm et al., 2006). Changes in freshwater inputs to the Arctic Ocean will therefore have global climatic implications beyond the drainage basins from which the water is derived.

The QUEST-Global Scale Impacts project (Todd et al., 2011; http://www.met.reading.ac.uk/research/quest-gsi/) is a global attempt to improve quantification of impacts and uncertainty associated with different rates and degrees of climate change on freshwater (and other) resources in a consistent way. Using specific climate scenarios, a unified climate change impact assessment was conducted on a number of river systems, including the Liard River Basin, despite the use of different hydrological models. Hydrological simulations of the freshwater resources from this mountainous high latitude environment are an important contribution to this global study.

One way to examine future changes in freshwater inputs is through the use of General Circulation Models (GCMs). Current climate projections from GCMs indicate preferential warming of the Canadian Arctic, relative to the global mean, which can have substantial secondary impacts on the environment (Bonsal and Kochtubajda, 2009). The major concern with assessing hydrological impacts using GCMs is the amount of uncertainty involved. Notable sources of uncertainty within an impact study are due to (1) GCM algorithms,

Published by Copernicus Publications on behalf of the European Geosciences Union. 
parameterization and feedback mechanisms, (2) downscaling techniques, and (3) hydrological modelling (Bormann, 2005; Hughes et al., 2010; Kriaučiūnienè et al., 2009; Ludwig et al., 2009; Prudhomme and Davies, 2009a). Prudhomme and Davies (2009a) found that hydrological uncertainty can be as large as the natural variability in the hydrological regime, but in comparison, uncertainty in the monthly mean flow simulated with input of climate data from different GCMs is much larger.

This inclusion of future climate uncertainty on hydrological impacts with the use of climate change scenarios is of recent concern (Cameron et al., 2000; Horton et al., 2006; Kriaučiūnienè et al., 2009; Maurer, 2007; Minville et al., 2008; Nawaz and Adeloye, 2006; Prudhomme and Davis, 2009a,b). For an Arctic climate, several studies have examined the impacts of future climate scenarios (Bonsal and Kochtubajda, 2009; Kattsov et al., 2007; Nohara et al., 2006), however, few have examined the hydrological impacts in this region. One exception is the study by Pohl et al. (2007) who examined the effects of GCM projections on a small Arctic headwater basin. Another is a study by Woo et al. (2008), who examined the response of the Liard River to climate change projected by the Canadian Centre for Climate Modeling and Analysis (CCCMA) GCM under the more conservative B2 emissions scenario. Since the largest uncertainty is found in the choice of the GCM selected, it is strongly recommended that outputs from several GCMs are used in an impact study (Prudhomme and Davis, 2009b).

Considering all of the above, this study will use a welltested, semi-distributed hydrological model to examine the uncertainty in the impacts of different projected climate change scenarios on the quantity and seasonality of water resources for a large, complex, mountainous, subarctic environment located in an area influenced by climatic warming. The major source of uncertainty considered is that derived from several GCM scenarios where (1) parameters and algorithms in the hydrological model have been held constant, as determining the range in which the values will vary is difficult to determine and has been found to contribute little towards the uncertainty (Kingston et al., 2011); (2) the day-today variability has been confined; and (3) it is assumed that there is no change in the land cover response to climate due to the difficulties in determining the future impacts on the loss of permafrost with respect to vegetation cover and soil properties (Yi et al., 2007). These constraints are consistent with the climate impact assessment approach by Parry and Carter (1998) adopted by the other papers within this special issue (Singh et al., 2010).

\section{Study area}

The Mackenzie River receives half of its annual runoff from mountainous regions that occupy less than one third of the total basin area, and most of this flow is produced

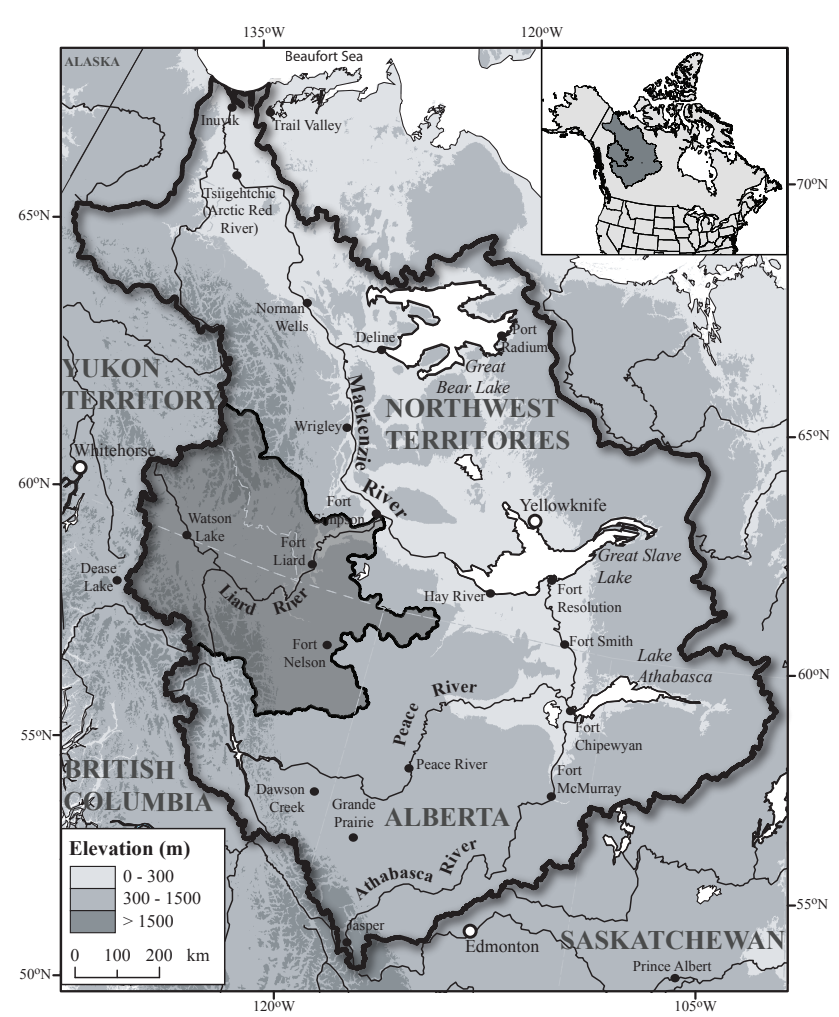

Fig. 1. Location of the Liard River in the Mackenzie River Basin.

in the spring (Woo and Thorne, 2003). The Liard River Basin, a major tributary of the Mackenzie River, drains an area of $275000 \mathrm{~km}^{2}$ and is a large, complex, mountainous, subarctic catchment in the Western Cordillera (Fig. 1). Three northwest-southeast trending mountain chains (Stikine Ranges, Selwyn and Rocky Mountains) occupy most of the basin, with elevation exceeding $3200 \mathrm{~m}$. Located at higher latitudes $\left(57-63^{\circ} \mathrm{N}\right)$, the basin has a cold temperate to subarctic setting, with a strong vertical zonation in the mountain climate. The Cordillera is effective in blocking most moisture-bearing winds from the Pacific Ocean and orographic precipitation is most notable in the western sector. Precipitation in the mountainous basin is significantly correlated with altitude and latitude, increasing with proximity to the Pacific Ocean but decreasing northeastward (Woo and Thorne, 2006). Snow is a major form of precipitation, but rainfall is common in the summer and autumn seasons. Runoff is characterized by a subarctic nival regime, in which snowmelt dominates, generating annual high flows in combination with summer rainfall (Woo and Thorne, 2003). Autumn rainfall gives rise to a secondary peak that is lower in magnitude than the spring flood. Winter runoff is low and sustained by groundwater discharge (van der Linden and Woo, 2003). Land cover in the basin is largely comprised of tundra, and both deciduous and evergreen forests. A complex basin of this nature would have many factors to consider in terms of uncertainty in the impact on the hydrological regime. 


\section{Data and methods}

\subsection{Climate data}

Mountainous environments, with complex topography and diverse surface covers, are subject to large variations in climatic conditions over short distances. Several weather stations provide point measurements of daily temperature and precipitation, but as these stations are located in valleys or flat ground, they do not provide adequate spatial coverage of climatic conditions within the vast area of the Liard River Basin. Without a good coverage of weather stations, hydrological models have to resort to interpolations of input values, an approach found suitable for remote mountainous areas such as those in subarctic Canada (Thorne and Woo, 2006).

To generate the required daily climate data for the model (precipitation, mean and minimum temperature), gridded $\left(0.5^{\circ} \times 0.5^{\circ}\right)$ monthly observations (CRU TS3.0) and climate projections (ClimGen) were transformed using a stochastic weather generator (Arnell, 2003; Todd et al., 2011). The weather generator was conditioned using climate station data statistics from five climate stations (Dease Lake, Fort Liard, Fort Nelson, Fort Simpson and Watson Lake) within and around the Liard River Basin (Fig. 1). These include: the coefficient of variation of daily precipitation (on days when rain occurs) and the standard deviation of daily temperature (after the seasonal cycle in temperature has been removed). The baseline dataset spans the period 1961 to 1990 during which the quality of the data generally increases towards the latter part of the period (Zhang et al., 2000). Although there are errors associated with the application of gridded, global-scale datasets, discrepancies most likely occur where the historical meteorological observations are sparse.

In this study, future climate scenarios for temperature and precipitation were generated using the ClimGen patternscaling technique described in Todd et al. (2011). Scenarios were generated for a prescribed warming of a global mean temperature of $1,2,3,4,5$, and $6^{\circ} \mathrm{C}$ using the UKMO HadCM3 GCM (HadCM3), and for a $2{ }^{\circ} \mathrm{C}$ global mean warming with six additional GCMs: CCCMA CGCM31 (CCCMA), CSIRO Mk30 (CSIRO), IPSL CM4 (IPSL), MPI ECHAM5 (MPI), NCAR CCSM30 (NCAR), and UKMO HadGEM1 (HadGEM1) applied to the baseline period (1961 to 1990) for this study. Year-to-year variability was excluded in the analysis of hydrological changes in the basin. The simulations assumed no change in land cover and soil conditions under a natural setting.

\subsection{Hydrometric data}

Rivers in the Liard Basin are not regulated and the hydrometeorological records permit the assessment of flow responses to changes in climatic conditions without the need to consider human interferences.
The Liard River is gauged at its mouth (at Fort Simpson, $61^{\circ} 44^{\prime} 49^{\prime \prime} \mathrm{N} 121^{\circ} 13^{\prime} 25^{\prime \prime} \mathrm{W}$ ), above the confluence with the Mackenzie River starting in 1973. Discharge data from this gauging station are used for calibration and for comparison with values simulated by the hydrological model.

\subsection{Analysis}

Temperature and precipitation distribution across the basin is examined, in addition to total basin annual precipitation and runoff, and monthly hydrographs produced by each future scenario. To simplify the analysis of both temperature and precipitation, four seasons were examined: winter (December to February), spring (March to May), summer (June to August) and autumn (September to November).

\section{Hydrological model and calibration}

For hydrological simulations, any hydrological model can be useful for this type of study; however, the SLURP (Semidistributed Land Use-based Runoff Processes) model (version 12.2) was selected for use as it has been well-tested in mountainous basins (Kite et al., 1994), particularly the Liard Basin (Thorne and Woo, 2006; Woo and Thorne, 2006). SLURP divides a large catchment into aggregated simulation areas (ASAs). The present study subdivides the Liard Basin into 35 ASAs, which partitions the basin into distinctive sub-basins, based on the United States Geological Survey (USGS) GTOPO-30 digital elevation model. Each ASA encompasses a number of land cover types, derived from the USGS $1 \mathrm{~km}$ digital land cover map of the world, characterised by a set of parameters. Mean elevation, area and areal percentages occupied by each land cover type are estimated from both the digital elevation data and land cover map. For evapotranspiration calculations, the Spittlehouse/Black evapotranspiration method (Spittlehouse, 1989), a modified form of the Priestley and Taylor approach, was chosen. Simulations using SLURP are based on: (1) a vertical component consisting of daily surface water balance and flow generation from several storages; and (2) a horizontal component of flow delivery within each ASA and channel routing to the basin outlet.

The model only allows calibration of parameters at the outlet of a basin, but simulated discharge may be observed from each ASA within the basin. Thorne and Woo (2006) found that although the model was able to generate streamflow that satisfactorily fits the measure discharge at the basin outlet, it does not imply the capability of the model to correctly simulate runoff contributions from various ASAs. Rather, the model makes use of the compensatory effects of overestimation and underestimation in simulated discharge from various ASAs to yield an aggregate discharge that agrees well with the basin outflow. In addition, van der Linden and Woo (2003) found that parameters calibrated at a basin outlet 
may yield erroneous results when applied to basins of various sizes, or with divergent physical characteristics, even within the same basin. Based on the results from these experiments, discharge will only be examined at the outlet of the Liard River Basin at Fort Simpson.

As discharge records started in 1973, the hydrological model was calibrated with the gauged station from 1973 to 1990 (Fig. 2) using gridded $\left(0.5^{\circ} \times 0.5^{\circ}\right)$ climate observations, CRU TS3.0 (Mitchell and Jones, 2005; http: //badc.nerc.ac.uk/data/cru/). The Shuffled Complex Evolution method of model autocalibration incorporated in SLURP was used to optimize the parameter values. The designated parameters and procedures used in the calibration are further described in Thorne and Woo (2006) and Woo and Thorne (2006). To eliminate any uncertainty created by the hydrological model, the parameters and algorithms were held constant.

The calibration yielded a Nash and Sutcliffe (1970) statistic of 0.75 and a root-mean-square error of $1347 \mathrm{~m}^{3} \mathrm{~s}^{-1}$ or a normalized root-mean-squared error of $8 \%$. Comparison of the monthly hydrographs (Fig. 2a) shows that the model simulates the measured discharge fairly well, but for some years, simulated high flows are lower than that observed. This is further highlighted in Fig. 2b, a scatter plot of measured versus generated monthly discharge values. Compared to the 1:1 line, it can be seen that the simulation is underestimating the high flow in some instances. Finally, mean monthly discharge values for 1973 to 1990 show the observed and simulated streamflow regimes (Fig. 2c) are similar despite a higher hydrograph rise in March and April, and lower peak and summer flow.

While no validation period was available to further test the model performance, and due to the time constraints of both the observed discharge records and gridded climate data, the calibration period shows a suitable fit to the observed discharge and the simulation can be effective in assessing the impacts on discharge.

\section{Uncertainty in climate variables}

\subsection{Spatial distribution of temperature and precipitation}

Spatial variations of the 30-year mean temperature and precipitation generated by the CRU TS3.0 data set and distribution of seasonal changes projected by the future climate scenarios were mapped over the Liard River Basin (Figs. 3 and 4). These maps aid in analyzing how river discharge is affected by specific changes in temperature and precipitation. Temperatures are shown to be generally warmer in the southeast and decrease northwest towards high latitude and higher elevation (Fig. 3a). Snowfall is highest at the southwestern corner of the basin during the winter season, while the eastern sector lies to the lee of the prevailing westerlies
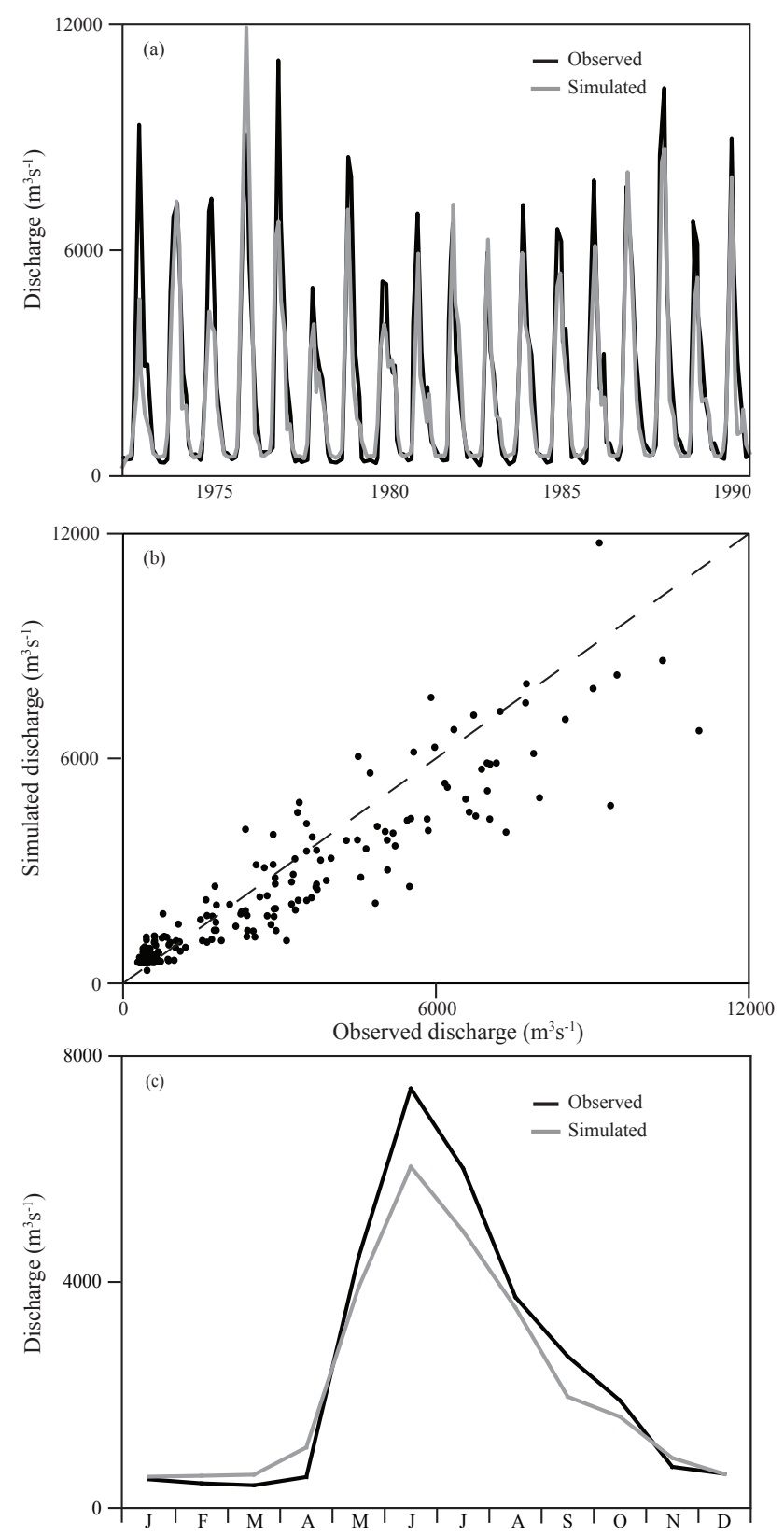

Fig. 2. Measured and simulated monthly discharge of the Liard River, at its outlet near Fort Simpson, are compared through the use of (a) hydrographs, (b) a scatter plot of the monthly values plotted with respect to a 1:1 line, and (c) the mean monthly discharge from 1973 to 1990 .

and generally has low winter precipitation (Fig. 4a). For the spring, heavier precipitation is seen in the southeastern corner of the basin. Summer produces the largest precipitation in all of the seasons, while autumn rainfall varies across the basin. 


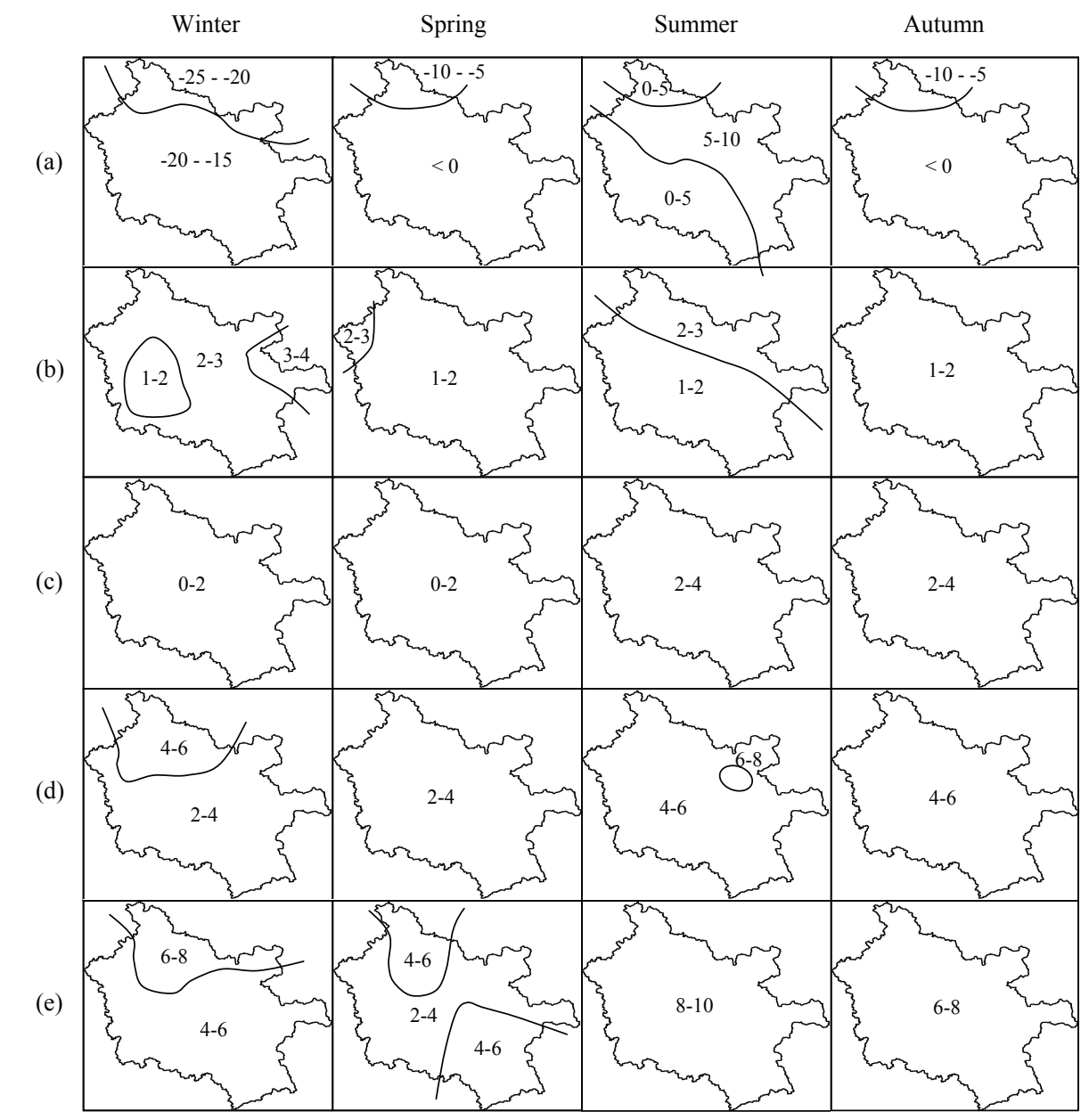

Fig. 3. (a) Spatial distribution of the 30 -year mean seasonal temperature generated by the CRU TS3.0 data set; (b) spatial variability of the absolute value between the maximum and minimum projected temperature between the seven GCMs under the $2^{\circ} \mathrm{C}$ prescribed warming scenario; distribution of seasonal changes in projected air temperature under the prescribed increases of (c) $2{ }^{\circ} \mathrm{C}$, (d) $4{ }^{\circ} \mathrm{C}$ and (e) $6{ }^{\circ} \mathrm{C}$ in the global mean air temperature by the UKMO HadCM3 GCM. The Liard Basin is outlined in black.

\subsection{Uncertainty in projected changes in air temperature}

Each climate scenario projected an increase in air temperature for each season across the basin. Instead of comparing the spatial changes projected by the individual scenarios, the spatial variability of the absolute value between the maximum and minimum projected change between the seven GCMs were mapped to highlight areas of the basin where more uncertainty in the temperature projections exist (Fig. 3b).

In the winter, the largest variation of temperature is in the eastern portion of the basin, decreasing westward. The spring shows a variation of $2-3{ }^{\circ} \mathrm{C}$ in the headwater area of the Liard, with the rest of the basin varying by $1-2^{\circ} \mathrm{C}$. A variation of $2-3^{\circ} \mathrm{C}$ is projected in northeastern portion of the basin during the summer, with the southwestern having only a $1-2{ }^{\circ} \mathrm{C}$ deviation. The entire basin varies by $1-2^{\circ} \mathrm{C}$ between the scenarios in the autumn.
Comparisons between all of the scenarios show an increase in air temperature for all seasons, in some cases with a variation of only $1{ }^{\circ} \mathrm{C}$. However, even a $1{ }^{\circ} \mathrm{C}$ temperature difference would impact the evaporation and freeze/melt rates within the basin. Winter has the largest range of projected warming, with $0-2{ }^{\circ} \mathrm{C}$ warming by the $\mathrm{HadCM} 3$ scenario and up to $6{ }^{\circ} \mathrm{C}$ for the CCCMA, MPI and HadGEM1 scenarios (individual projections not shown). On an annual basis, the highest projected temperature changes were by the MPI and IPSL scenarios. Most climate projections suggest a warming temperature in the Liard Basin greater than the global prescribed warming of $2{ }^{\circ} \mathrm{C}$.

The steady global temperature increase in the HadCM3 scenario projects a steady increase for all seasons. Only the temperature increases for the 2,4 and $6{ }^{\circ} \mathrm{C}$ scenarios are illustrated in Fig. 3. Winter and spring seasons have a temperature increase of $0-2{ }^{\circ} \mathrm{C}$, while summer and autumn both increase by $2-4^{\circ} \mathrm{C}$ in the $2^{\circ} \mathrm{C}$ scenario (Fig. 3c). These temperature changes double in the $4{ }^{\circ} \mathrm{C}$ scenario, with higher 


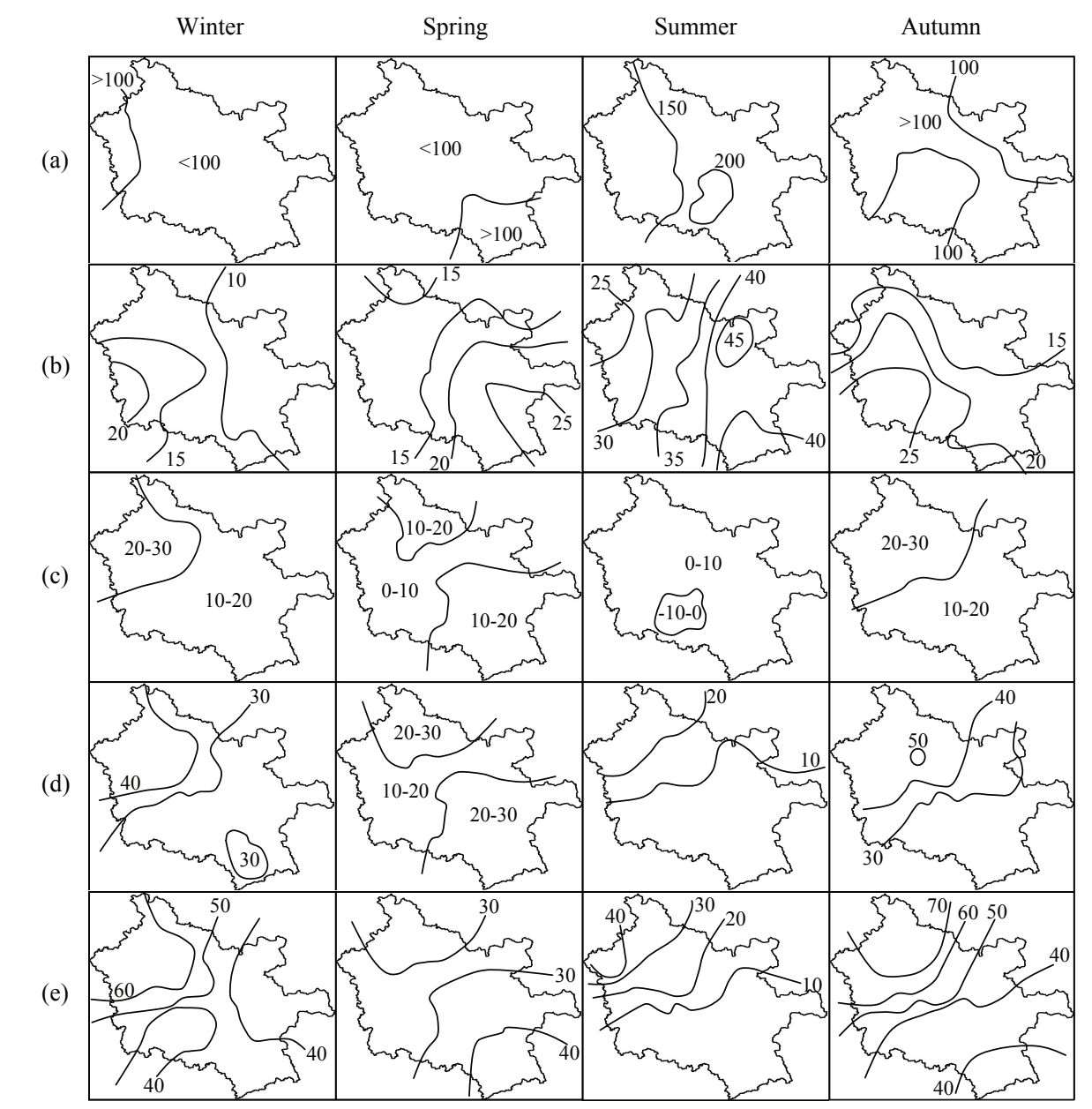

Fig. 4. (a) Spatial distribution of the 30-year mean seasonal precipitation generated by the CRU TS3.0 data set; (b) spatial variability of the absolute value between the maximum and minimum projected precipitation between the seven GCMs under the $2^{\circ} \mathrm{C}$ prescribed warming scenario; distribution of seasonal changes in projected precipitation under the prescribed increases of (c) $2{ }^{\circ} \mathrm{C}$, (d) $4{ }^{\circ} \mathrm{C}$ and (e) $6{ }^{\circ} \mathrm{C}$ in the global mean air temperature by the UKMO HadCM3 GCM. The Liard Basin is outlined in black.

temperature increases in the northern portion of the basin in the winter, and a small area near the outlet for the summer (Fig. 3d). Finally, the $6^{\circ} \mathrm{C}$ scenario doubles the temperature increases seen in the $4{ }^{\circ} \mathrm{C}$ scenario, except in the spring where northern and southern areas of the basin have increased by $4-6^{\circ} \mathrm{C}$ (Fig. 3e).

\subsection{Uncertainty in projected changes in precipitation}

Spatial precipitation changes projected by the future climate scenarios for each season were also generated, but similar to temperature, the spatial variability of the absolute value between the maximum and minimum projected change between the seven GCMs were mapped in Fig. 4b. Precipitation projections generally show an increase in the Liard River Basin, but these projections vary greatly spatially and by magnitude depending on the scenario, unlike the projections for temperature.
In the winter season, most scenarios project a large increase of precipitation in the western sector of the basin, although the magnitude varies with each scenario, which gives rise to the large variation in mountain areas. The largest winter increases are projected by the CCCMA and HadCM3 scenarios, while the CSIRO, NCAR and HadGEM1 scenarios have the lowest (individual projections not shown). Spring has the smallest seasonal increase by all the scenarios, with an increase of 10-20 mm for the CCCMA and HadGEM1 scenarios and a projected decrease in precipitation over the eastern portion of the basin from the IPSL scenario. Scenario projections in the summer differ greatly from one another. The CCCMA scenario has the largest increase of up to $40 \mathrm{~mm}$ in the eastern sector, while the IPSL, MPI and HadGEM1 scenarios project a decrease in this area. The HadCM3 scenario has little change across the basin. These differences produce the largest variability seen in all the seasons, especially in the eastern portion of the basin, with a 
Table 1. Calculated percent differences of average and standard deviation (squared brackets) values for annual basin precipitation and annual computed runoff between baseline (1961 to 1990) and future scenarios in the Liard River Basin. Round brackets indicate a negative value.

\begin{tabular}{lrrlrr}
\hline Scenario & $\begin{array}{c}\text { Average } \\
\text { precipitation }\end{array}$ & $\begin{array}{c}\text { Average } \\
\text { computed } \\
\text { runoff }\end{array}$ & Scenario & $\begin{array}{c}\text { Average } \\
\text { precipitation }\end{array}$ & $\begin{array}{r}\text { Average } \\
\text { computed } \\
\text { runoff }\end{array}$ \\
\hline Baseline & $481 \mathrm{~mm}$ & $231 \mathrm{~mm}$ & Baseline & $481 \mathrm{~mm}$ & $231 \mathrm{~mm}$ \\
CCCMA & $18 \%[2 \%]$ & $15 \%[1 \%]$ & HadCM3 $1{ }^{\circ} \mathrm{C}$ & $5 \%[3 \%]$ & $4 \%[1 \%]$ \\
CSIRO & $8 \%[1 \%]$ & $4 \%[2 \%]$ & HadCM3 $2{ }^{\circ} \mathrm{C}$ & $10 \%[4 \%]$ & $9 \%[3 \%]$ \\
HadCM3 & $10 \%[4 \%]$ & $9 \%[3 \%]$ & HadCM3 $3{ }^{\circ} \mathrm{C}$ & $15 \%[4 \%]$ & $12 \%[5 \%]$ \\
IPSL & $6 \%[8 \%]$ & $(3) \%[5 \%]$ & HadCM3 $4{ }^{\circ} \mathrm{C}$ & $21 \%[4 \%]$ & $18 \%[8 \%]$ \\
MPI & $13 \%[22 \%]$ & $6 \%[3 \%]$ & HadCM3 $5{ }^{\circ} \mathrm{C}$ & $26 \%[3 \%]$ & $23 \%[9 \%]$ \\
NCAR & $12 \%[4 \%]$ & $9 \%[2 \%]$ & HadCM3 $6{ }^{\circ} \mathrm{C}$ & $31 \%[2 \%]$ & $28 \%[13 \%]$ \\
HadGEM1 & $6 \%[5 \%]$ & $0 \%[8 \%]$ & & & \\
\hline
\end{tabular}

range of $45 \mathrm{~mm}$. Autumn projections show high precipitation increases by the CCCMA and HadCM3 scenarios, while other scenarios show moderate increases basin-wide. Moderate variations in projected precipitation are seen in the southwestern portion of the basin, decreasing northeast towards the outlet. The CCCMA and MPI scenarios have the largest increase in annual precipitation, with the CSIRO, IPSL and HadGEM1 scenarios projecting the lowest increase.

For the steadily warming HadCM3 scenarios (Fig. 4c-e), temperature increases in the basin also project an increase in precipitation. In each season there is a large increase of precipitation in the north and a moderate increase in the south, except in the spring, where an opposite pattern occurs. For the $2{ }^{\circ} \mathrm{C}$ scenario, the autumn and winter seasons have the largest increase in precipitation, with little change in the spring and summer. As the scenario temperature increases, basin-wide precipitation increases by at least $10 \mathrm{~mm}$, except in the summer, where precipitation only increases in the northwest sector.

\section{Streamflow Response}

\subsection{Uncertainty in projected changes of basin runoff}

After running the hydrological model using climate data from each scenario as input, percent differences of average and standard deviation values between the baseline period and future scenarios for annual precipitation and annual computed runoff were calculated for the basin (Table 1). Compared to baseline values, all scenarios project an increase in precipitation ( 6 to $18 \%$ ) however; runoff yielded highly uncertain results ranging from a decrease of $3 \%$ to an increase of $15 \%$. The HadGEM1 scenario simulates a similar amount of runoff compared to the baseline, while the IPSL scenario generates a loss of $3 \%$. With each degree of warming under the HadCM3 GCM, both precipitation and runoff increased by at least $5 \%$.
Table 2. Calculated differences of seasonal runoff between the baseline (1961 to 1990) and future scenarios in the Liard River Basin. Round brackets indicate a negative value.

\begin{tabular}{lrcrr}
\hline \multicolumn{1}{c}{ Scenario } & $\begin{array}{c}\text { Winter } \\
\text { Runoff }(\%)\end{array}$ & $\begin{array}{c}\text { Spring } \\
\text { Runoff }(\%)\end{array}$ & $\begin{array}{c}\text { Summer } \\
\text { Runoff }(\%)\end{array}$ & $\begin{array}{c}\text { Autumn } \\
\text { Runoff }(\%)\end{array}$ \\
\hline CCCMA & 11 & 28 & 10 & 21 \\
CSIRO & 5 & 19 & $(3)$ & 12 \\
HadCM3 & 4 & 26 & 1 & 14 \\
IPSL & 5 & 41 & $(22)$ & 11 \\
MPI & 12 & 33 & $(11)$ & 28 \\
NCAR & 7 & 24 & 2 & 14 \\
HadGEM1 & 5 & 34 & $(12)$ & 1 \\
HadCM3 $1{ }^{\circ} \mathrm{C}$ & 2 & 13 & 0 & 9 \\
HadCM3 $2{ }^{\circ} \mathrm{C}$ & 4 & 26 & 1 & 14 \\
HadCM3 3 ${ }^{\circ} \mathrm{C}$ & 7 & 39 & 2 & 22 \\
HadCM3 $4{ }^{\circ} \mathrm{C}$ & 12 & 54 & 0 & 32 \\
HadCM3 5 ${ }^{\circ} \mathrm{C}$ & 20 & 71 & $(1)$ & 44 \\
HadCM3 $6{ }^{\circ} \mathrm{C}$ & 31 & 86 & 56 \\
\hline
\end{tabular}

\subsection{Uncertainty in projected changes in intra-annual river discharge}

To investigate changes in the streamflow response brought on by the future scenarios, hydrological simulations were performed and the results were averaged into monthly intervals over the 30-year period (Table 2).

Monthly hydrographs simulated using the $2{ }^{\circ} \mathrm{C}$ prescribed warming scenarios (Fig. 5) indicate an alteration to the hydrological regime and magnitude of discharge to the Liard River. A notable feature is the increase of winter low flow for all scenarios (4 to $12 \%$ ) due to the higher recession flow from the larger autumn rainfall events. Warmer spring temperatures lead to an earlier arrival of snowmelt runoff. The MPI and IPSL scenarios have the highest spring runoff as a result of higher projected temperatures for the spring season (Sect. 5.2). With the increased precipitation in the winter and 


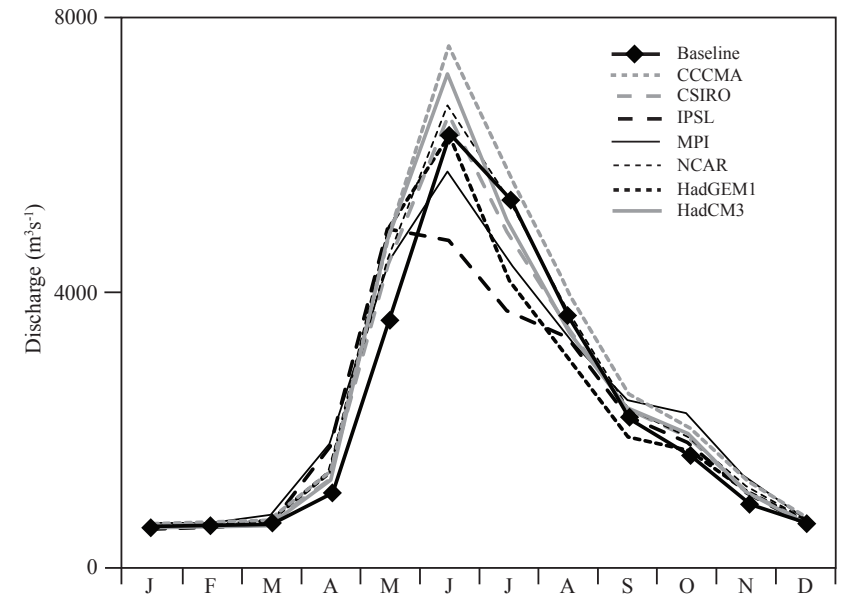

Fig. 5. Comparison of baseline and projected mean monthly river discharge under the $2{ }^{\circ} \mathrm{C}$ prescribed warming scenario for seven GCMs.

spring for most scenarios, the high flows (with increases of 19 to $41 \%$ ) continue into the summer. An earlier melt season and an increase in winter snow accumulation can extend the basin snowmelt over a longer period. An early melt year depletes the snow gradually so that runoff becomes less concentrated (Woo and Thorne, 2006).

Beyond the spring flow, the MPI, IPSL and HadGEM1 scenarios (higher temperatures in the summer, an increase in winter snowfall, and spring and summer precipitation lower than the baseline) result in a lower peak flow, or in the case of the HadGEM1 scenario, a similar peak flow compared to the baseline. The IPSL scenario projects the primary peak flow to occur a month earlier than the baseline. The CCCMA and HadCM3 scenarios both have the highest peak flow. Summer flow from the scenarios, with the exception of a $10 \%$ increase by CCCMA, is projected to be lower than the baseline, with a loss of up to $22 \%$ (Table 2). For these scenarios, an increase in summer rainfall does not compensate for an increase in evaporation created by higher temperatures. The autumn months show an increase in the secondary peak for all scenarios (1 to $28 \%$ ). The highest flow is generated by MPI, which also has the largest increase in autumn precipitation.

The impact by the warming HadCM3 scenarios on the discharge of the Liard River (Fig. 6) shows similar findings. As the temperature warms, discharge increases from autumn to spring months due to an increase in precipitation, with the largest increase during the spring (up to $86 \%$, Table 2). An increase in temperature, which will increase the evaporation rate, balanced by an increase in precipitation will create little change in total summer runoff. The autumn secondary peak is enhanced by each degree of warming (up to $56 \%$ ).

Uncertainty in projected temperature and precipitation changes by the $2{ }^{\circ} \mathrm{C}$ prescribed warming scenarios creates discrepancies with regards to the projections of river

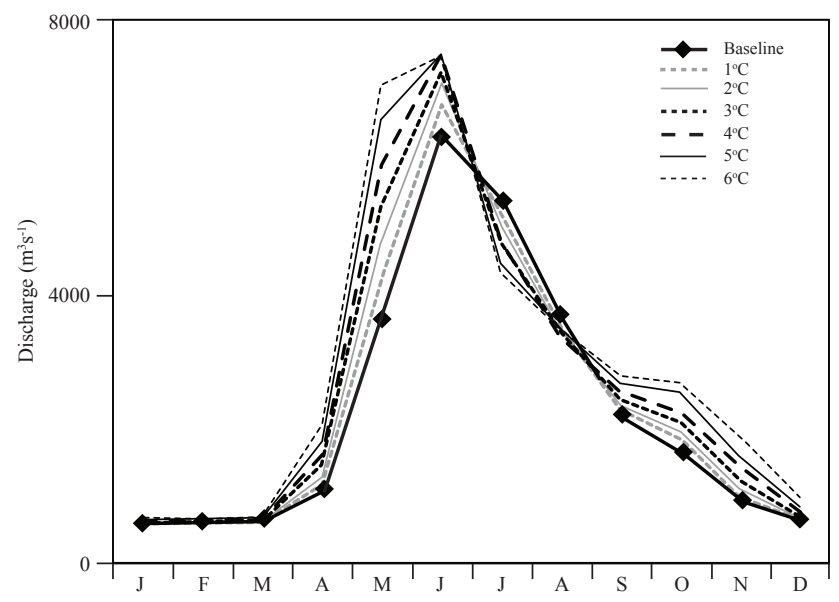

Fig. 6. Comparison of baseline and projected mean monthly river discharge under prescribed increases of 1 to $6^{\circ} \mathrm{C}$ in global mean air temperature by the UKMO HadCM3 GCM.

discharge. Results show that the subarctic nival regime of the Liard River will be preserved. Winter and spring flow will increase generating an earlier rise in spring freshet. Primary and secondary discharge peaks will be maintained but will show an advancement of the monthly flows. Summer flow will decrease, but will be balanced by an increase in the autumn. However, the magnitude of change in flow differs between the scenarios.

\section{Discussion and conclusions}

Like many high latitude areas, the mountainous region of subarctic Canada has experienced recent warming and it is an area of large inter-annual temperature variations, notably during the winter season (Zhang et al., 2000). Quantifying how climate tendencies affect streamflow, especially in the spring melt season, is critical not only to regional water resource management but to understanding the influence of freshwater on the Arctic sea-ice cover and global climate system (Rennermalm et al., 2006). The scarcity of climate stations in the remote region prevents a comprehensive appraisal of climatic influences on discharge, but results from global gridded observations (CRU TS3.0) and projections permit the analysis through the availability of spatial information.

Uncertainty in the impacts of (1) seven GCMs with $2{ }^{\circ} \mathrm{C}$ prescribed increase in global mean air temperature and (2) scaled increases in global mean air temperature of 1 to $6^{\circ} \mathrm{C}$ using the HadCM3 GCM on river discharge were examined. Hydrological modelling was used to simulate the effects of climate change on streamflow. To avoid the potential effects of uncertainties caused by the hydrological model SLURP, model parameters were held constant. Uncertainties between the GCM scenarios were driven by the 


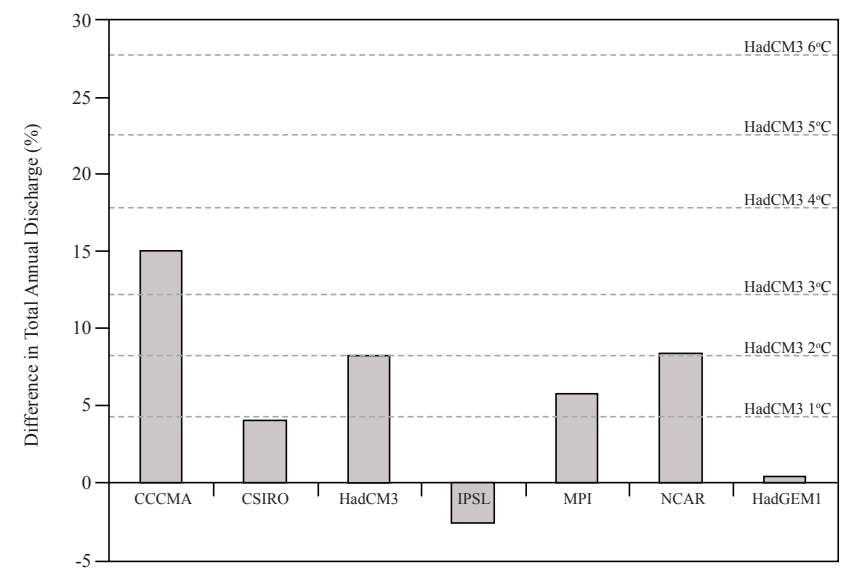

Fig. 7. Differences in the total annual discharge between the baseline values and future climate scenarios. Values from the seven GCMs are shown by the grey bars whereas values generated by the scaled increase in global mean air temperature of 1 to $6^{\circ} \mathrm{C}$ using the HadCM3 GCM, are shown with dash lines.

inconsistencies in projected spatial variability and magnitude of precipitation rather than warming temperatures. The case study of the Liard River, in the absence of major land-use changes in the basin, found qualitative agreements regarding the tendencies of streamflow response to various GCM scenarios, though the impacts vary in detail, the simulations offer a quantification of the differences in flow response. All scenarios indicate that the subarctic nival regime will be preserved in the future, but with a shift towards an earlier rise in spring runoff and peak discharge. However, the magnitude of change in the discharge has a high degree of uncertainty due to projected differences in the increase of temperature and precipitation within the basin.

To better illustrate the uncertainty in projecting streamflow in the Liard River Basin, Fig. 7 shows a comparison in the difference of total annual discharge between the baseline values and future climate change scenarios. The degree of uncertainty amongst the scenarios is evident. Most scenarios project a change in discharge below the level projected by the $2{ }^{\circ} \mathrm{C} \mathrm{HadCM} 3$ prescribed warming scenario. The CCCMA scenario is an exception with a change in discharge above the level projected by the $3{ }^{\circ} \mathrm{C}$ increase in HadCM3 scenario. The HadGEM1 scenario shows very little change in annual discharge while IPSL shows a projected decrease. Even with a $2{ }^{\circ} \mathrm{C}$ prescribed global warming amongst the scenarios, algorithms, parameterization and feedback mechanisms within the GCMs will give rise to different outcomes.

Freshwater contribution to the Mackenzie River (and subsequently the Arctic Ocean) from the Liard Basin will generally increase, which can have an impact on the sea ice cover and Arctic atmosphere. An increase in freshwater discharge will reduce sea ice volume and thereby potentially reduce the thermohaline circulation (Rennermalm et al., 2006).
Current studies on trends and variability in the Liard Basin (Abdul Aziz and Burn, 2006; Burn, 2008; Burn et al., 2004; Woo et al., 2008) indicate that the results projected by the climate scenarios are plausible since historical records indicate an increase in winter flow, an earlier onset of spring runoff due to increasing trends in temperature, and a summer flow decrease related to more frequent warm summers, that leads to greater evaporation. Uncertainty in the current projections of the impacts of climate change in the Liard River presents an indication of projected changes in the quantity and seasonality of water resources. Reducing uncertainty associated with the scenarios is problematic due to the inherently different model structures of the GCMs in addition to inadequate ground-based measurements. Consideration into the use of several different GCMs is recommended, and to assist with projections in an area sensitive to climate forcing, hydrometeorological monitoring networks must be maintained, and even intensified.

Acknowledgements. Climate scenarios and support for this research were facilitated by a grant from the UK Natural and Environmental Research Council (NERC), under the Quantifying and Understanding the Earth System (QUEST) programme (Ref. NE/E001890/1). I am most appreciative of the helpful comments from Ming-ko Woo, Richard Taylor, Julian Thompson and the two anonymous reviewers.

Edited by: J. Thompson

\section{References}

Abdul Aziz, O. I. and Burn, D. H.: Trends and variability in the hydrological regime of the Mackenzie River Basin, J. Hydrol., 319, 282-294, 2006.

Arnell, N. W.: Effects of IPCC SRES* emissions scenarios on river runoff: a global perspective, Hydrol. Earth Syst. Sci., 7, 619641, doi:10.5194/hess-7-619-2003, 2003.

Bonsal, B. R. and Kochtubajda, B.: An assessment of present and future climate in the Mackenzie Delta and the near-shore Beaufort Sea region of Canada, Int. J. Climatol., 29, 1780-1795, 2009.

Bormann, H.: Evaluation of hydrological models for scenario analyses: signal-to-noise-ratio between scenario effects and model uncertainty, Adv. Geosci., 5, 43-48, doi:10.5194/adgeo-5-432005, 2005.

Burn, D. H.: Climatic influences on streamflow timing in the headwaters of the Mackenzie River Basin, J.Hydrol., 352, 225-238, 2008.

Burn, D. H., Cunderlik, J. M., and Pietroniro, A.: Hydrological trends and variability in the Liard River basin, Hydrolog. Sci. J., 49, 53-67, 2004.

Cameron, D., Beven, K., and Naden, P.: Flood frequency estimation by continuous simulation under climate change (with uncertainty), Hydrol. Earth Syst. Sci., 4, 393-405, doi:10.5194/hess4-393-2000, 2000.

Horton, P., Schaefli, B., Mezghani, A., Hingray, B., and Musy, A.: Assessment of climate-change impacts on alpine discharge regimes with climate model uncertainty, Hydrol. Process., 20, 2091-2109, 2006. 
Hughes, D. A., Kapangaziwiri, E., and Sawunyama, T.: Hydrological model uncertainty assessment in southern Africa, J. Hydrol., 387, 221-232, 2010.

Kattsov, V. M., Walsh, J. E., Chapman, W. L., Govorkova, V. A., Pavlova, T. V., and Zhang, X.: Simulation and projection of Arctic freshwater budget components by the IPCC AR4 global climate models, J. Hydrometeorol., 8(3), 571-589, 2007.

Kingston, D. G., Thompson, J. R., and Kite, G.: Uncertainty in climate change projections of discharge for the Mekong River Basin, Hydrol. Earth Syst. Sci., 15, 1459-1471, doi:10.5194/hess-15-1459-2011, 2011.

Kite, G. W., Dalton, A., and Dion, A.: Simulation of streamflow in a macroscale watershed using general circulation model data, Water Resour. Res., 30, 1547-1559, 1994.

Kriaučiūnienė, J., Šarauskienė, D. and Gailiušis, B.: Estimation of uncertainty in catchment-scale modelling of climate change impact (case of the Merkys River, Lithuania), Environ. Res. Eng. Manage., 1(47), 30-39, 2009.

Ludwig, R., May, I., Turcotte, R., Vescovi, L., Braun, M., Cyr, J.F., Fortin, L.-G., Chaumont, D., Biner, S., Chartier, I., Caya, D., and Mauser, W.: The role of hydrological model complexity and uncertainty in climate change impact assessment, Adv. Geosci., 21, 63-71, doi:10.5194/adgeo-21-63-2009, 2009.

Maurer, E. P.: Uncertainty in hydrologic impacts of climate change in the Sierra Nevada, California, under two emissions scenarios, Climatic Change, 82, 309-325, 2007.

Minville, M., Brissette, F., and Leconte, R.: Uncertainty of the impact of climate change on the hydrology of a nordic watershed, J. Hydrol., 358, 70-83, 2008.

Mitchell, T. D. and Jones, P. D.: An improved method of constructing a database of monthly climate observations and associated high-resolution grids, Int. J. Climatol., 25, 693-712, 2005.

Nash, J. E. and Sutcliffe, J. V.: River flow forecasting through conceptual models: Part 1 - a discussion of principles, J. Hydrol., 10, 282-290, 1970.

Nawaz, N. R. and Adeloye, A. J.: Monte Carlo assessment of sampling uncertainty of climate change impacts on water resources yield in YorkShire, England, Climatic Change, 78, 257-292, 2006.

Nohara, D., Kitoh, A., Hosaka, M., and Oki, T.: Impact on climate change on river discharge projected by multimodel ensemble, J. Hydrometeorol., 7(5), 1076-1089, 2006.

Parry, M. and Carter, T.: Climate Impact and Adaptation Assessment, A Guide to the IPCC Approach, Earthscan, London, UK, 166 pp., 1998.

Pohl, S., Marsh, P., and Bonsal, B. R.: Modeling the impact of climate change on runoff and annual water balance of an arctic headwater basin, Arctic, 60(2), 173-186, 2007.
Prudhomme, C. and Davies, H.: Assessing uncertainties in climate change impact analyses on the river flow regimes in the UK, Part 1: baseline climate, Climatic Change, 93, 177-195, 2009a.

Prudhomme, C. and Davies, H.: Assessing uncertainties in climate change impact analyses on the river flow regimes in the UK, Part 2: future climate, Climatic Change, 93, 197-222, 2009b.

Rennermalm, A. K., Wood, E. F., Déry, S. J., Weaver, A. J., and Eby, M.: Sensitivity of the thermohaline circulation to Arctic Ocean runoff, Geophys. Res. Lett., 33, L12703, doi:10.1029/2006GL026124, 2006.

Singh, C. R., Thompson, J. R., French, J. R., Kingston, D. G., and Mackay, A. W.: Modelling the impact of prescribed global warming on runoff from headwater catchments of the Irrawaddy River and their implications for the water level regime of Loktak Lake, northeast India, Hydrol. Earth Syst. Sci., 14, 1745-1765, doi:10.5194/hess-14-1745-2010, 2010.

Spittlehouse, D. L.: Estimating evapotranspiration from land surfaces in British Columbia, in: Estimation of Areal Evapotranspiration, IAHS Publ., 177, 245-253, 1989.

Thorne, R. and Woo, M. K.: Efficacy of a hydrologic model in simulation discharge from a large mountainous catchment, J. Hydrol., 330, 301-312, 2006.

Todd, M. C., Taylor, R. G., Osborn, T. J., Kingston, D. G., Arnell, N. W., and Gosling, S. N.: Uncertainty in climate change impacts on basin-scale freshwater resources - preface to the special issue: the QUEST-GSI methodology and synthesis of results, Hydrol. Earth Syst. Sci., 15, 1035-1046, doi:10.5194/hess-151035-2011, 2011.

van der Linden, S. and Woo, M. K.: Transferability of hydrological model parameters between basins in data-sparse areas, subarctic Canada, J. Hydrol., 270, 182-194, 2003.

Woo, M. K. and Thorne, R.: Streamflow in the Mackenzie Basin, Canada, Arctic, 56(4), 328-340, 2003.

Woo, M. K. and Thorne, R.: Snowmelt contribution to discharge from a large mountainous catchment in subarctic Canada, Hydrol. Process., 20, 2129-2139, 2006.

Woo, M. K., Thorne, R., Szeto, K. K., and Yang, D.: Streamflow hydrology in the boreal region under the influences of climate and human interference, Philos. T. Roy. Soc. B, 363, 2249-2258, 2008.

Yi, S., Woo, M. K., and Arain, M. A.: Impacts of peat and vegetation on permafrost degradation under climate warming, Geophys Res. Lett., 34, L16504, doi:10.1029/2007GL030550, 2007.

Zhang, X., Vincent, L. A., Hogg, W. D., and Niitsoo, A.: Temperature and precipitation trends in Canada during the 20th century, Atmos. Ocean, 38(3), 395-429, 2000. 